Portland State University

PDXScholar

\title{
A Comparative Assessment of Projected Meteorological and Hydrological Droughts: Elucidating the Role of Temperature
}

\author{
Ali Ahmadalipour \\ Portland State University \\ Hamid Moradkhani \\ Portland State University \\ Mehmet C. Demirel \\ Portland State University
}

Follow this and additional works at: https://pdxscholar.library.pdx.edu/cengin_fac

Part of the Climate Commons, and the Environmental Indicators and Impact Assessment Commons Let us know how access to this document benefits you.

\section{Citation Details}

Ahmadalipour, Ali; Moradkhani, Hamid; and Demirel, Mehmet C., "A Comparative Assessment of Projected Meteorological and Hydrological Droughts: Elucidating the Role of Temperature" (2017). Civil and Environmental Engineering Faculty Publications and Presentations. 414.

https://pdxscholar.library.pdx.edu/cengin_fac/414

This Post-Print is brought to you for free and open access. It has been accepted for inclusion in Civil and Environmental Engineering Faculty Publications and Presentations by an authorized administrator of PDXScholar. Please contact us if we can make this document more accessible: pdxscholar@pdx.edu. 
Ali Ahmadalipour ${ }^{*}$, Hamid Moradkhani, and Mehmet C. Demirel Remote Sensing and Water Resource Lab, Department of Civil and Environmental Engineering, Portland State University, Portland, OR 97201, USA

6

*Corresponding Author, email: aahmad2@pdx.edu

7 


\section{Abstract}

The changing climate and the associated future increases in temperature are expected to have impacts on drought characteristics and hydrologic cycle. This paper investigates the projected changes in spatiotemporal characteristics of droughts and their future attributes over the Willamette River Basin (WRB) in the Pacific Northwest U.S. The analysis is performed using two subsets of downscaled CMIP5 global climate models (GCMs) each consisting of 10 models from two future scenarios (RCP4.5 and RCP8.5) for 30 years of historical period (1970-1999) and 90 years of future projections (2010-2099). Hydrologic modeling is conducted using the Precipitation Runoff Modeling System (PRMS) as a robust distributed hydrologic model with lower computational cost compared to other models. Meteorological and hydrological droughts are studied using three drought indices (i.e. Standardized Precipitation Index, Standardized Precipitation Evapotranspiration Index, Standardized Streamflow Index). Results reveal that the intensity and duration of hydrological droughts are expected to increase over the WRB, notwithstanding that the annual precipitation is expected to increase. On the other hand, the intensity of meteorological droughts do not indicate an aggravation for most cases. We explore the changes of hydrometeolorogical variables over the basin in order to understand the causes for such differences and to discover the controlling factors of drought. Furthermore, the uncertainty of projections are quantified for model, scenario, and downscaling uncertainty.

\section{Keywords:}

Drought, PRMS, SPI, SPEI-PM, SSI, Willamette 


\section{INTRODUCTION}

Dry soil and low water table in aquifers, reservoirs, lakes, and rivers are all different reflections/types of drought. Drought is a complex phenomenon listed among severe natural hazards developing slowly and affecting large areas as compared to the eye-catching flash-flood events (Dai, 2012; Demirel et al., 2013; Van Loon and Van Lanen, 2013). Drought can hamper river navigation, water supply, agriculture, hydropower generation, and increase the risk of forest fire and mortality of livestock (Chen and Sun, 2017; Sun et al., 2015a; Turner et al., 2015).

Scientific reports on drought risk have pointed out the importance of these events and the need for more efforts to investigate the spatiotemporal development of both meteorological and hydrological droughts in addition to the floods (Van Loon, 2015; Vicente-Serrano et al., 2015). Especially after the unprecedented hot winter recorded in 2014 in the PNW, drought in Oregon attracted significant attention from the media. Therefore, it is of interest to assess the impacts of climate change and anthropogenic warming on meteorological and hydrological droughts in the Willamette River Basin, as one of the most populated basins in the region, and identify the linkages between these two types of droughts, and also quantify the uncertainty in future projections.

Previous studies have shown that under climate change scenarios, future annual precipitation is expected to increase over the Pacific Northwest US (Ahmadalipour et al., 2017a; Mote and Salathé, 2010; Rana and Moradkhani, 2015). Moreover, the seasonality and spatial distribution of precipitation will also change (Feng et al., 2013; Jiang et al., 2016), which makes it difficult to provide a clear conclusion of the effects of climate change on meteorological droughts. Furthermore, the increase in temperature will affect several hydrological processes such as evapotranspiration and snowmelt (Diffenbaugh et al., 2013; Sima et al., 2013). This makes assessing hydrological droughts more challenging as streamflow is an integral variable of 
precipitation, evaporation, snowmelt, and soil moisture (Berghuijs et al., 2014; Mazrooei et al., 2015). Therefore, analyzing various drought indices that consider different parameters is important for drought-prone areas.

Quantifying hydrological drought as an independent phenomena has received a lot of consideration, since there is usually no direct relationship between meteorological and hydrological droughts in terms of intensity, duration, and onset (Hannaford et al., 2011). Van Loon (2015) described the temporal lag among different types of drought, and demonstrated the importance of analyzing hydrological drought.

There are a number of indices developed for assessing droughts. Schyns et al. (2015) reviewed and classified numerous drought indices, most of which are estimated using a combination of precipitation, temperature, potential evaporation (PE) or potential evapotranspiration (PET), soil moisture, runoff, and streamflow. For example, Sohrabi et al. (2015) developed a new soil moisture drought index to characterize droughts. Furthermore, few studies have reviewed the application of remotely sensed observations for drought monitoring purposes (Ahmadalipour et al., 2017b; Anderson et al., 2013). The appropriate index is selected based on the targetted type of drought as the calculation may differ significantly among indices.

Several studies have shown the role of temperature in drought (Ahmadalipour et al., 2016; Diffenbaugh et al., 2015; Shukla et al., 2015; Williams et al., 2015). To better understand the impact of global warming on drought, it is recommended to account for temperature effects as well (Dai, 2011; Jeong et al., 2014; Strzepek et al., 2010). Recently, Ahmadalipour et al. (2016) conducted a comprehensive assessment of future drought projections at seasonal timescale. They used SPI and SPEI calculated from downscaled GCMs to investigate the changes in drought characteristics over the contiguous United States (CONUS) with and without considering the role of temperature, as a means to better assess drought in a warming climate. They found intensifying drought condition in western United States, and identified the 
superiority of SPEI over SPI, as the former accounts for potential evapotranspiration (PET) variations.

Abatzoglou et al. (2014) used several drought indices to evaluate the interannual streamflow variability and hydrometeorological drought occurrences in the U.S. Pacific Northwest over the historical period of 1948-2012. They found that the indices computed using high-resolution climate surfaces explained over $10 \%$ more variability than metrics derived from coarserresolution datasets. Jung and Chang (2012) used eight CMIP3 GCMs (Coupled Model Intercomparison Project Phase 3 Global Climate Models) and applied SPI and SRI to analyze the changes in probability of future drought across different regions of Willamette Basin and assessed the spatial patterns. They concluded that the decrease in summer precipitation and snowmelt are the main factors causing an increase in the number of short-term droughts.

Most of the above efforts have focused on the development of a new drought index or the assessment of climate change impact on specific indices (Azmi et al., 2016; Kharin et al., 2013; Safeeq et al., 2014). Relationship and differences between meteorological and hydrological droughts using various scenarios and ensemble of downscaled climate model outputs has not been explicitly assessed in many studies, and a lot of studies only consider one type of drought. This is an important issue which can better indicate the socio-economic impacts of climate change, and it has not been investigated extensively over the Willamette Basin.

The objective of this study is to assess the historical and future characteristics of meteorological and hydrological droughts over the Willamette River Basin in the Pacific Northwest U.S. We aim to investigate the changes of drought characteristics in a region with abundant water resources, which is expected to receive even more precipitation in future. Moreover, by utilizing different combinations of GCMs, concentration pathways, and downscaling methods, we address the uncertainties arised from these sources. 
102 The paper is organized as follows: study are and data are explained in the next section, followed

103 by explanation of hydrologic model calibration and the attributes of drought indices in the

104 methodology section. Then, the results for meteorological and hydrological drought

105 characteristics are provided in the results section and discussed afterwards, and the main

106 findings of the study are summarized at the end.

\section{STUDY AREA AND DATA}

108 The study area is the Willamette River Basin (WRB) with a drainage area of $29,700 \mathrm{~km}^{2}$ near

109 the Cascade Mountains in Western Oregon, U.S. (Halmstad et al., 2013). The basin is a densely

110 populated river basin accommodating more than 3 million inhabitants and 25 dams (Jung and

111 Chang, 2012). It is located between a low lying valley and high cascade ranges, with temperate

112 marine climate. The basin elevation varies from 65 to $3106 \mathrm{~m}$ (Figure 1) and mean annual

113 precipitation varies from about $1000 \mathrm{~mm}$ to above $3000 \mathrm{~mm}$ at different regions of the basin.

114 More than half of the basin ( $68 \%)$ is covered by forests, around $20 \%$ is used for agriculture,

115 and the remaining 12\% is urbanized area (Jung and Chang, 2012).

116

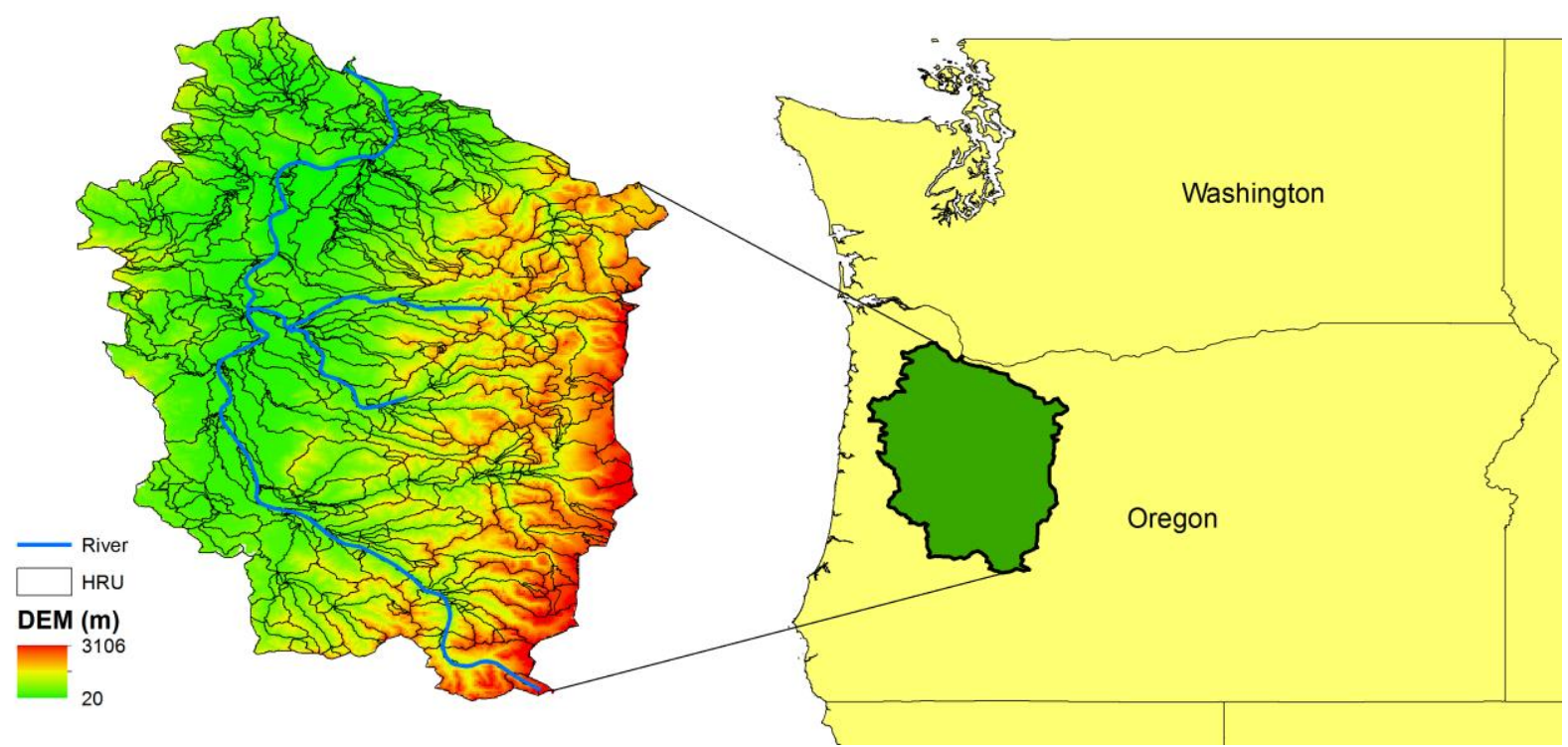

117 Figure 1. The Willamette River Basin located in the Pacific Northwest, U.S. 


\subsection{Observation data}

119 In this study, we have used naturalized streamflow series, i.e. the No Regulation No Irrigation

120 (hereafter called NRNI data), at 20 calibration points at the outlet of homogeneous response

121 units to calibrate the Precipitation Runoff Modeling System (PRMS) model

122 (http://www.bpa.gov/power/streamflow/default.aspx). In addition to the streamflow data, we

123 have utilized gridded daily precipitation (Pr) and daily maximum and minimum temperature

124 (Tmax and Tmin) data from the University of Idaho (Abatzoglou and Brown, 2012) as well as

125 the climate forcing dataset provided by Livneh et al. (2013). The gridded meteorological forcing

126 data is spatially averaged over the HRUs using the USGS Geo Data Portal

127 (http://cida.usgs.gov/gdp/) for hydrologic modeling purposes.

\subsection{Downscaled and bias-corrected climate model outputs}

129 Statistically downscaled and bias-corrected climate data from 10 Global Climate Models

130 (GCMs) participating in CMIP5 (Taylor et al., 2012) are utilized here (Table 1). These GCMs

131 are selected according to a multivariate statistical framework reported by Ahmadalipour et al.

132 (2015). All 10 GCMs were downscaled to 1/16 degree spatial resolution using the Bias

133 Correction and Spatial Disaggregation (BCSD) method (Wood et al., 2002) generated at

134 Portland State University (Rana and Moradkhani, 2015). In addition, another downscaled

135 product, i.e. Multivariate Adaptive Constructed Analogs (MACA) (Abatzoglou and Brown,

136 2012), is used in our comparative study. Data for MACAv2-Livneh is downloaded from the

137 MACA website at http://maca.northwestknowledge.net/. All the models and data are acquired

138 and used at a daily timescale. The RCP4.5 and RCP8.5 scenarios from both BCSD and MACA

139 ensembles are used for future projections. The historical period of 1970-1999 and future period

140 of 2010-2099 are considered for the analysis. Similar to the observed gridded input data, BCSD

141 and MACA data are also averaged over the HRUs using the USGS Geo Data Portal in order to

142 run the hydrologic model and analyze the simulated discharge over the WRB. 
144 Table 1. The 10 GCMs used in this study and their characteristics.

\section{METHODOLOGY}

147 The observed and simulated precipitation, Tmax, Tmin, and wind data from 20 GCMs (10

148 BCSD and 10 MACA) were used to assess the historical and future characteristics of

149 meteorological droughts in the WRB. Using the climate forcing from 20 GCMs as input to

150 PRMS hydrologic model, the streamflow is simulated and used to address the changes in

151 hydrological droughts. Further, a comparison is carried out between meteorological and

152 hydrological drought characteristics in order to better understand the impacts of climate change.

\section{$153 \quad 3.1 \quad$ Hydrologic Modelling}

154 The US Geological Survey's Precipitation Runoff Modelling System (PRMS) is a physically

155 based semi-distributed hydrologic model utilized in this study to simulate historical and future

156 streamflow in the Willamette basin (Leavesley et al., 1995). The PRMS runs at a daily time

157 step and requires daily precipitation, and minimum and maximum air temperature averaged

158 over the user-defined homogeneous response units (HRUs). The model has been successfully

159 applied in numerous studies to model the watersheds and assess the effects of land use and

160 climate change (Jung et al., 2011; Legesse et al., 2003; Najafi et al., 2011; Risley et al., 2011).

161 The HRUs correspond to grid cells in distributed hydrologic models, as they are considered

162 homogeneous units which can produce and exchange flow between each other, connected to

163 the atmosphere and to the river network consisting of stream segments and lakes (Risley et al., 164 2011). 


\subsection{Model Calibration and Validation}

166 In total, 669 HRUs (shown in Figure 1) were delineated based on the national Geospatial Fabric

167 database created by the USGS National Research Program, Denver, Colorado using 168 topographic, hydrographic, land use, soil, and vegetation data layers. The HRUs were defined 169 by Points of Interest (POIs) which include USGS flow gages, NWS forecast sites, 500m 170 elevation bands, travel times less than one day, and major confluences. Downstream sub-basins 171 (i.e. total of 20 sub-basins) were calibrated with estimated no-regulation no-irrigation (NRNI) streamflow data. Calibrated model parameters are described in Table 2.

173

174 175

Table 2. The parameters calibrated in each step of the calibration process.

For the calibration, a USGS calibration tool (i.e. LUCA) was used. LUCA (Hay et al., 2006; Hay and Umemoto, 2007) is a wizard-style user-friendly GUI providing a systematic way of building and executing a multiple-objective, stepwise, automated calibration based on the Shuffled Complex Evolution global search algorithm (Duan et al., 1993). Historical streamflow data for the period of 1979-2003 and 2004-2008 were used to calibrate and validate the model, respectively. The calibration and validation of the PRMS were performed using four different measures, i.e. Kling-Gupta Efficiency (KGE) measure (Gupta et al., 2009), Nash-Sutcliffe Efficiency (NSE) measure (Nash and Sutcliffe, 1970), Root Mean Square Error (RMSE), and Bias.

\subsection{Drought indices}

Several drought indices have been used by various researchers to characterize different types of drought. For this study, we have used Standardized Precipitation Index (SPI) (McKee et al., 1993), Standardized Precipitation Evapotranspiration Index (SPEI) (Vicente-Serrano et al., 
2010), and Standardized Streamflow Index (SSI) (Nalbantis and Tsakiris, 2009; Shukla and

190 Wood, 2008). The SPI and SPEI assess meteorological drought, whereas SSI characterizes the

191 hydrological drought. It should be noted that the indices are developed in a standardized form;

192 therefore, they consider the same thresholds.

\subsubsection{Standardized Precipitation Index (SPI)}

194 The SPI, introduced by McKee et al. (1993), is one of the most widely used drought indices

195 which quantifies the deviation of precipitation from historical mean for a region. It is one of the

196 primary drought indices used operationally by the World Meteorological Organization (WMO)

197 and the National Drought Mitigation Center for drought monitoring (Huang et al., 2015; Swain

198 and Hayhoe, 2015). A SPI of zero indicates that rainfall is equal to the mean of historical record.

199 In this study, SPI is calculated for 12-month accumulation period using non-parametric Weibull 200 plotting position as follows:

$201 P\left(x_{i}\right)=\frac{i}{n+1}$

where $\mathrm{i}$ is the rank of precipitation from smallest to largest, $\mathrm{n}$ denotes the sample size, and $P\left(x_{i}\right)$ is the empirical probability. Then, $P\left(x_{i}\right)$ is transformed into the standard normal function with zero mean and standard deviation of one, which will be considered as the SPI value.

$205 S P I=\phi^{-1}(P)$

\subsubsection{Standardized Precipitation Evapotranspiration Index (SPEI)}

207 SPEI was developed by Vicente-Serrano et al. (2010), and has been applied in numerous studies. The procedure to calculate SPEI involves a climatic water balance, and it considers the role of temperature in drought assessment. SPEI is based on variations in the deficit of

210 precipitation and potential evapotranspiration (P-PET). Previously, Palmer Drought Severity 211 Index (PDSI) (Palmer, 1965) was introduced considering variations in several supply/demand 
212 variables of hydrologic cycle. However, PDSI lacks the multi-scalar feature and needs

213 calibration to be used in different locations (Vicente-Serrano et al., 2010). Furthermore, PDSI

214 is not a standardized index and does not follow the same thresholds as other standardized

215 drought indices.

216 Various methods have been proposed for calculating PET. Some studies have compared the 217 methods for calculating PET (Lu et al., 2005; Sheffield et al., 2012), and it has been shown that 218 Penman-Monteith (PM) (Allen et al., 1998) method provides more accurate results because of 219 having a more physically-based formulation of atmospheric evaporative demand (Donohue et 220 al., 2010). Therefore, our SPEI calculation is based on Penman-Monteith equation with the 221 Hargreaves-Samani modification (Hargreaves and Samani, 1985) as described in the FAO-56 222 (Allen et al., 1998). The chosen PM method is recommended by World Meteorological 223 Organization (WMO) as the standard technique for estimating PET, and it has been proven to 224 be accurate with low data requirements (Stagge et al., 2015).

225 After calculating PET, the deficit (D) will be calculated as the difference between precipitation 226 and potential evapotranspiration:

$227 \quad D_{i}=P_{i}-P E T_{i}$

228 D will then be accumulated on 12-month timescale (starting at each month), and is used to 229 calculate SPEI for each month. Various studies have utilized different distribution functions to 230 calculate SPEI such as L-moment ratio diagrams (Vicente-Serrano et al., 2010), Log-logistic 231 (Touma et al., 2015), and GEV (Stagge et al., 2015). Here, the Weibull function (equation 1) is 232 utilized to calculate SPEI from the deficit calculated by equation 3. Similar to SPI, SPEI is also 233 calculated at 12-month accumulation period for each grid cell and for each GCM. 


\subsubsection{Standardized Streamflow Index}

235 Researchers have developed standardized hydrological drought indices similar to those 236 available for meteorological drought. Two of the most well-known standardized hydrological 237 drought indices are the Standardized Runoff Index (SRI) (Shukla and Wood, 2008), and 238 Streamflow Drought Index (SDI) (Nalbantis, 2008; Nalbantis and Tsakiris, 2009). These two 239 indices have similar theoretical background as both try to transform monthly streamflow into 240 standardized normal distribution (with zero mean and unit variance, similar procedure as in 241 SPI) and calculate hydrological drought index.

242 In this study, we have utilized Standardized Streamflow Index (SSI) calculated based on non243 parametric approach. The procedure is simple and similar to that explained for SPI; the 12244 month accumulated streamflow values for each month are assessed separately, and SSI is 245 calculated for each month. The benefit of this approach is that it is less subjective than 246 distribution fitting methods, and it results in a standardized hydrological drought index which 247 can be classified and compared to meteorological drought results.

248 All drought indices are calculated using the non-parametric Weibull function (described in 249 section 3.3.1) for the 12-month accumulation period. Since the study period is 120 years (30 250 years of historical and 90 years of future period), investigating variations in 12-month indices 251 can reveal the possible mid to long-term changes and trends induced by climate change. SPI and SPEI are calculated for each of the 1/16 degree grids, and SSI is calculated using the

253 streamflow at the outlet of the basin.

\subsection{Drought classification}

255 The classification of drought and corresponding probability for each class are according to 256 McKee et al. (1993). Since all the three drought indices used in this study are standardized 257 indices, they have the same thresholds for each category. The categories are defined based on 
certain probability thresholds. A drought index of -1 to $-1.49,-1.5$ to -1.99 , and less than -2 corresponds to moderate, severe, and extreme drought, respectively.

\subsection{Drought characteristics}

For each drought index, several main characteristics of drought are studied:

- Duration of drought

- Frequency of drought (number of events)

- Intensity of drought

The first two characteristics, i.e. the duration and number of events, are studied for the periods of 1970-1999 (historical), 2010-2039 (near future), 2040-2069 (intermediate future), and 2070-2099 (distant future). Long-term trends in the intensity of drought are assessed for 90 years of future period (2010-2099) using Mann-Kendall trend test as a rank-based nonparametric test, independent of the statistical distribution of data (Kendall, 1948).

\section{RESULTS}

\subsection{Calibration and validation of hydrologic model}

Table 3 shows the calibration and validation of the PRMS daily results. The model performs reasonably well at all 20 NRNI points except for Oak Grove ( $15^{\text {th }}$ NRNI point) with a KGE of 0.42 for calibration period and 0.38 for validation period. The validation performance of the model at the $19^{\text {th }}$ NRNI point, i.e. TWSulliwan, the outlet of the WRB is 0.73 (KGE).

Table 3. Calibration and validation results at 20 NRNI points. The values in parentheses show the model performance over validation period. Note that the outlet of WRB is at TWSullivan, SVN5N. 


\subsection{Meteorological drought}

\subsubsection{Meteorological drought frequency}

283 Figure 2 shows the changes in the number of meteorological drought events for 30-year periods 284 of future scenarios compared to the historical period of 1970-1999 according to the two drought indices. An event is counted when the drought index is below -1 (moderate to extreme drought condition) and may range from a short period drought to a long-lasting drought of several months. The historical observed drought events for SPEI and SPI are about 12 and 11, 288 respectively. Comparing the results from SPEI and SPI, the latter shows a decrease in the 289 number of drought events, since the SPI solely considers precipitation variations. Annual projections of climate variables are plotted in Figure S1, which reflects the long-term changes.

291 Assessing the changes in frequency of drought using the SPEI reveals increasing number of

292 drought events in most cases. In general, BCSD shows more increase in drought events than 293 MACA. All SPEI projections indicate an increase in drought frequency for southern parts of 294 the basin.

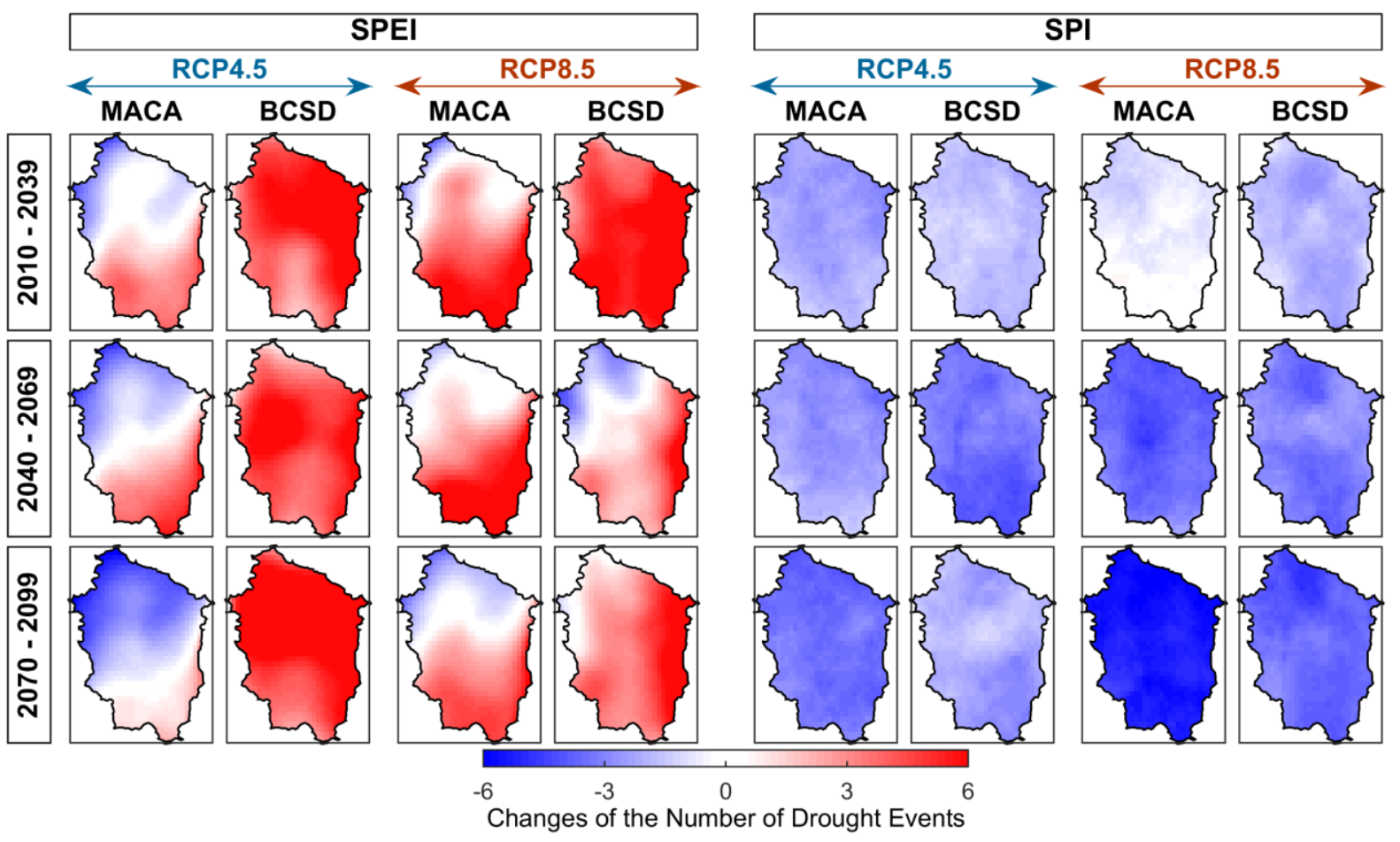


296 Figure 2. The change in the number of meteorological drought events for 30-year periods. Each plot is 297 based on the ensemble mean of drought events from 10 GCMs.

\subsubsection{Meteorological drought duration}

299 Figure 3 shows the spatially averaged duration of each meteorological drought class across the 300 Willamette Basin. Duration of meteorological drought is calculated for SPEI and SPI using 301 each of the $10 \mathrm{GCMs}$ of MACA and BCSD datasets. Figure 3 provides the drought duration for 302 each drought class in each time span. Drought duration calculated from GCMs are spatially 303 averaged over the basin, and the ensemble mean of 10 GCMs is plotted in Figure 3. The

304 historical observed duration of moderate, severe, and extreme drought are about 35, 12, and 11 305 months, respectively. Comparing the two indices, SPEI indicates higher duration of drought 306 than SPI. BCSD shows longer drought duration than MACA in most cases. Further, BCSD 307 indicates a considerable increase in duration of extreme drought condition for both SPEI and 308 SPI. For instance, considering SPI results for BCSD-RCP8.5, although the total duration of 309 drought is $\sim 60$ months, duration of extreme drought shows about $50 \%$ and $100 \%$ increase for 310 near and intermediate future, respectively. On the other hand, SPI results from MACA dataset 311 indicate a decrease in duration of moderate drought. 


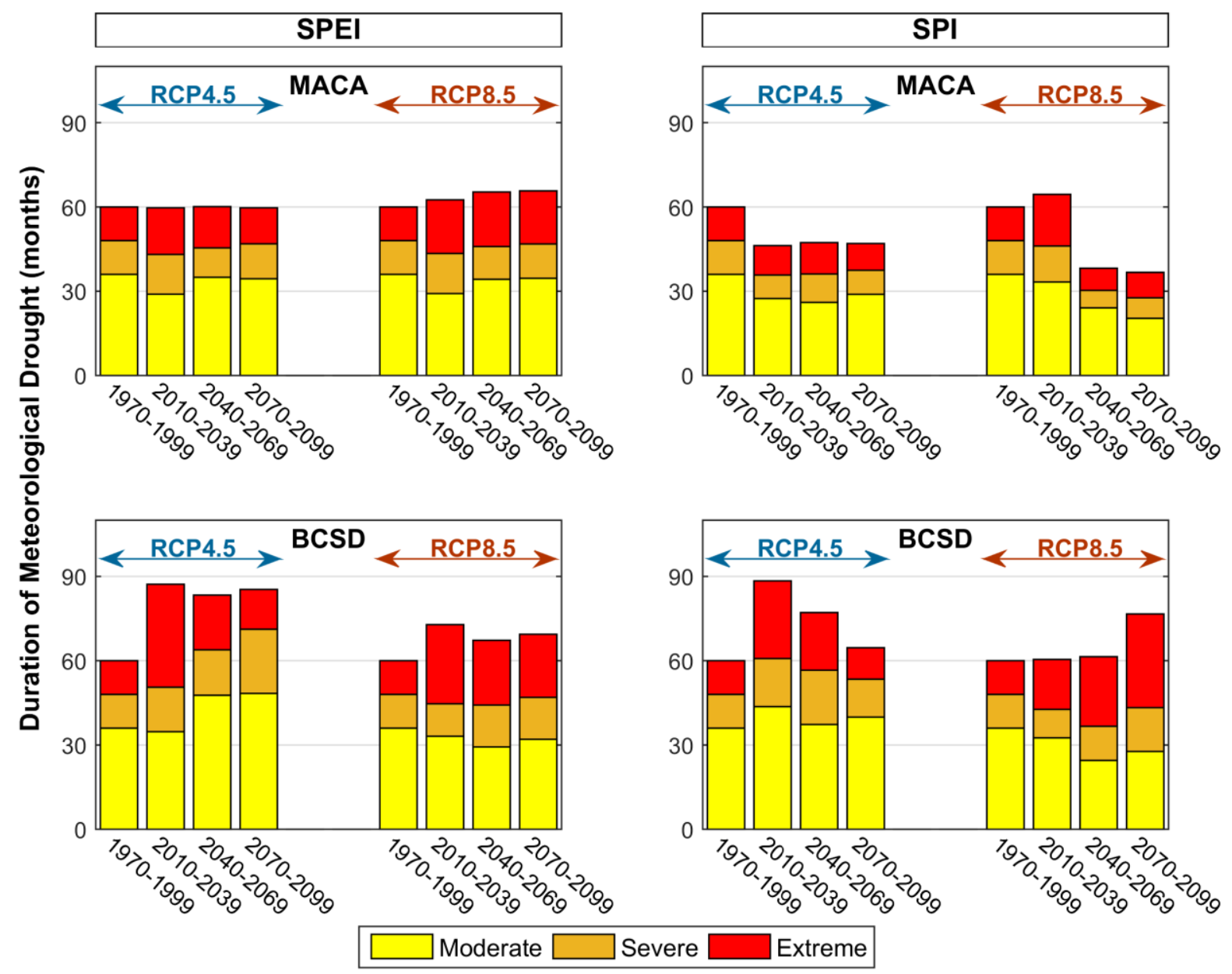

Figure 3. Duration of meteorological drought in 30-year intervals.

\subsubsection{Meteorological drought intensity}

315 Figure 4 shows the linear trend of SPEI and SPI calculated for each GCM over the period of 2010-2099 for both MACA and BCSD under RCP8.5. The top two rows show the trends for

317 SPEI and the bottom two rows show the trends of SPI. Results of the 10 GCMs are plotted 318 followed by the ensemble mean trend. In each plot, a negative trend (red color) indicates 319 decreasing value of drought index and hence intensified future droughts, and vice versa. There 320 is a large difference among the results of different models for SPEI. Comparing the results of 321 SPEI and SPI, SPEI indicates more intensification in future droughts than SPI in most cases. 322 Considering the ensemble mean of models (the right plots), SPI shows slightly positive trend 323 (decreasing intensity of future droughts) while SPEI shows slightly negative trend (increasing 
intensity of future droughts). Comparing the RCP8.5 and RCP4.5 results (provided in the
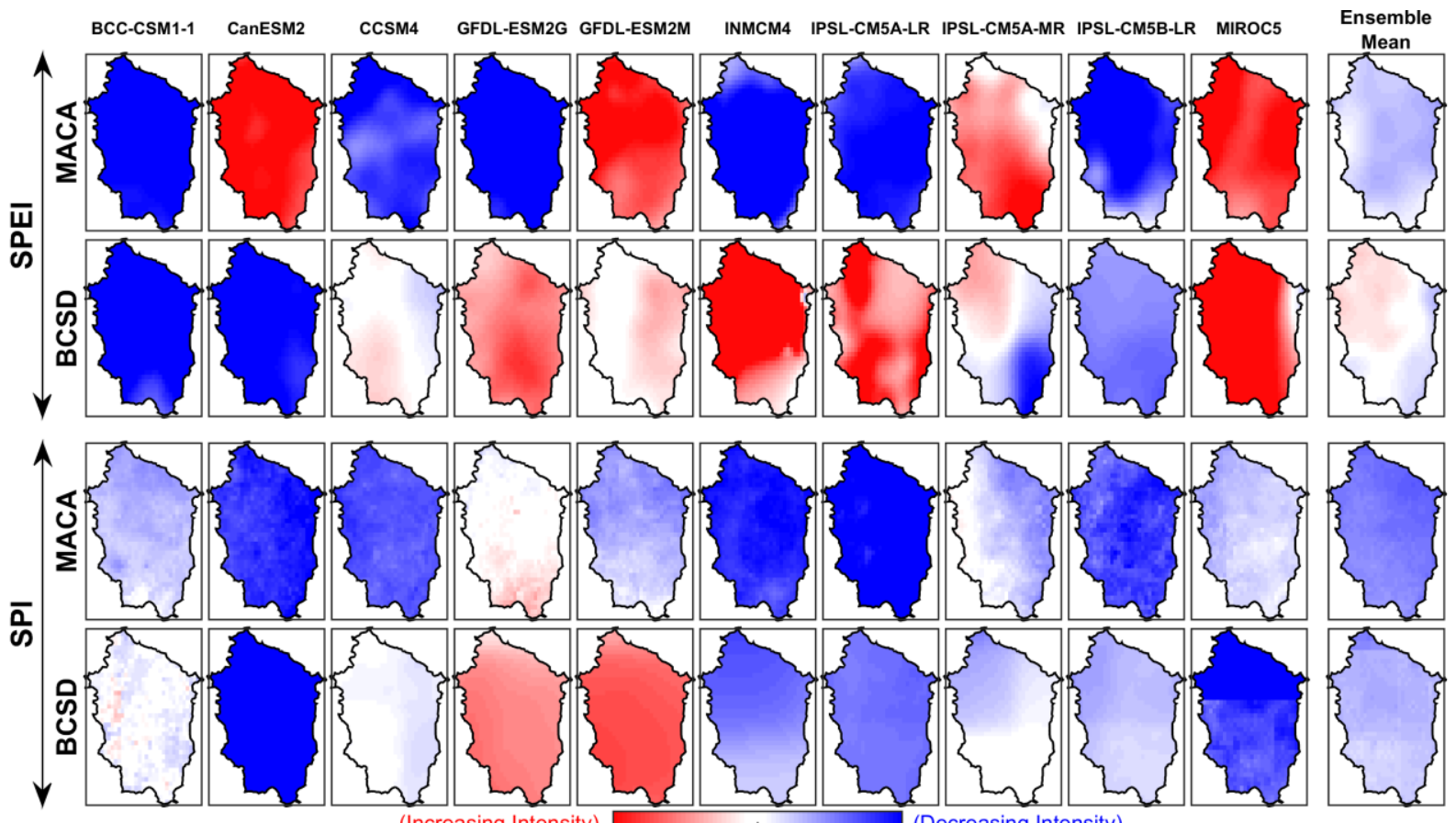

Figure 4. Long-term trend of meteorological drought for each GCM in RCP8.5 scenario. Trend is calculated for the period of 2010-2099 for each GCM, with the ensemble mean trend plotted on the right.

\subsection{Hydrological drought}

\subsubsection{Streamflow simulation}

333 Hydrologic simulations by the PRMS model and driven by the MACA and BCSD downscaled climate data are shown in Figure 5. In the figure, the observed streamflow is shown in green followed by the simulation results from the $10 \mathrm{GCMs}$ for historical period (black), RCP4.5 (blue), and RCP8.5 (red). The figure reveals the dual behavior of future streamflow in highflow and low-flow months. The results show a decreasing trend for simulated flow in spring 338 (Apr, May, and Jun), whereas winters (Dec, Jan, and Feb) indicate an increase in the simulated 
streamflow. In other words, warmer winters result in higher winter flow and less snowpack to melt as spring flow. The model simulations by MACA and BCSD datasets indicate similar results, again with the dual pattern for both datasets. Comparing the streamflow projections

342 from the two concertation pathways, it is seen that the RCP8.5 results in higher streamflow than RCP4.5 during December to February. Whereas during April to October, RCP8.5 projects lower

344 streamflow than RCP4.5. Uncertainty associated with concentration pathways is mostly 345 noticeable in December for both datasets. Further, historical GCM runs tend to underestimate 346 observed streamflow in January and May, while overestimate it in November. For other months, 347 both datasets show reasonable performance in the historical period.
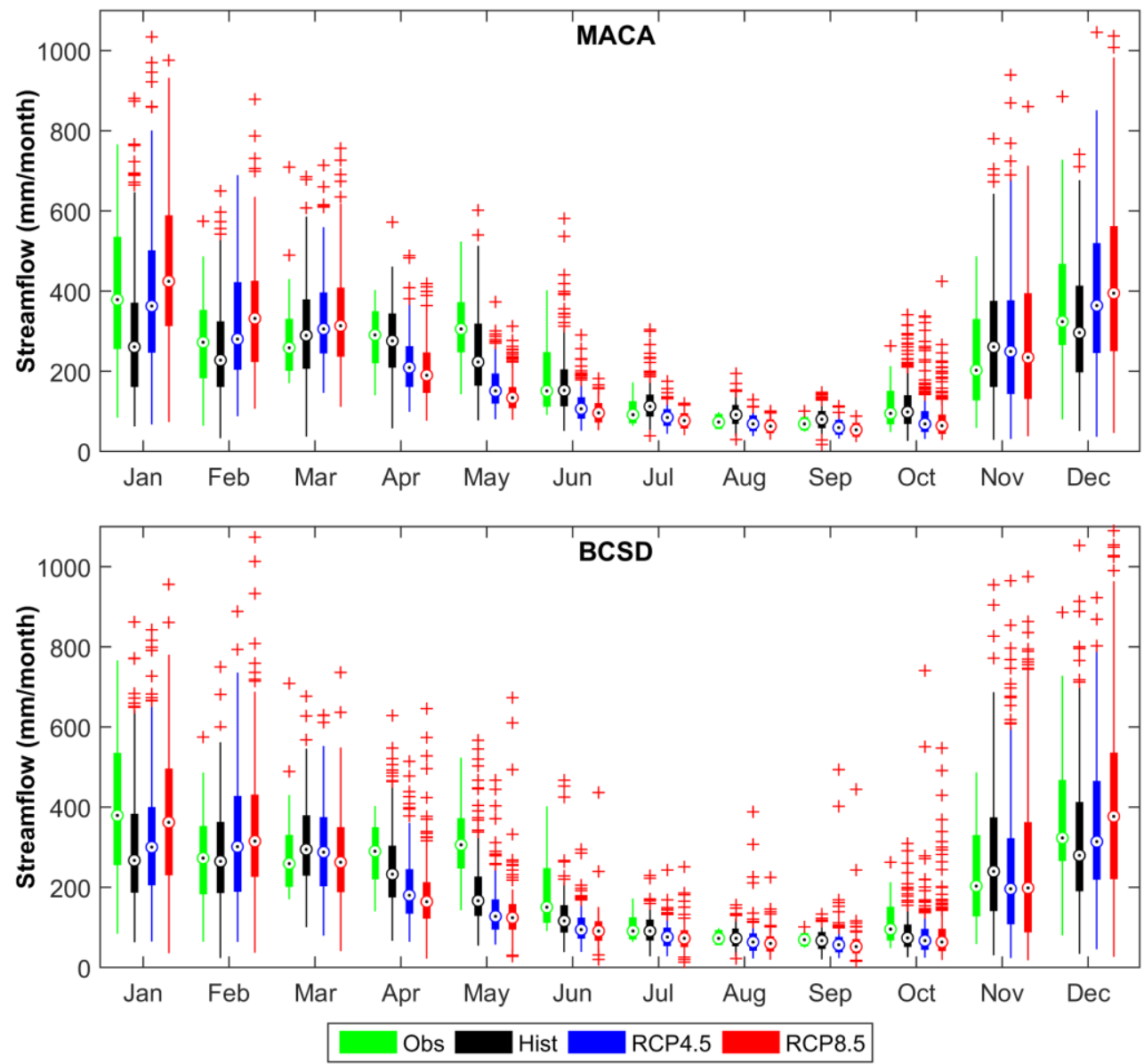

349 Figure 5. Observed and simulated monthly streamflow forced by MACA (top) and BCSD (bottom) datasets at the outlet of Willamette Basin. 


\subsubsection{Hydrological drought frequency}

352 Standardized Streamflow Index (SSI) is calculated for each GCM in each dataset, and the 353 number of hydrological drought events is extracted for 30-year intervals. Figure 6 shows the 354 number of hydrological drought events over 30-year historical and future periods. The 355 observation indicates 9 hydrological droughts during the historical period over the basin. 356 Considering inter-model variations (model uncertainty), INMCM4 shows the least number of 357 drought events in almost all cases. Models show vast uncertainty in projected drought 358 frequency. Some models show different behavior between RCP4.5 and RCP8.5; for instance, 359 GFDL-ESM2G indicates the highest number of drought events in RCP4.5, while it shows 360 infrequent events in RCP8.5 scenario. Comparing the two datasets, BCSD usually shows more 361 frequent droughts than MACA. Generally, BCSD ensemble for RCP4.5 indicates the largest 362 number of hydrological drought events among the four cases. The boxplot at the bottom of 363 Figure 6 demonstrates that the median of the number of hydrological drought events (red line 364 in the middle of each box) does not change significantly over time and all scenarios project 365 about eight drought events in each 30-year time span. 

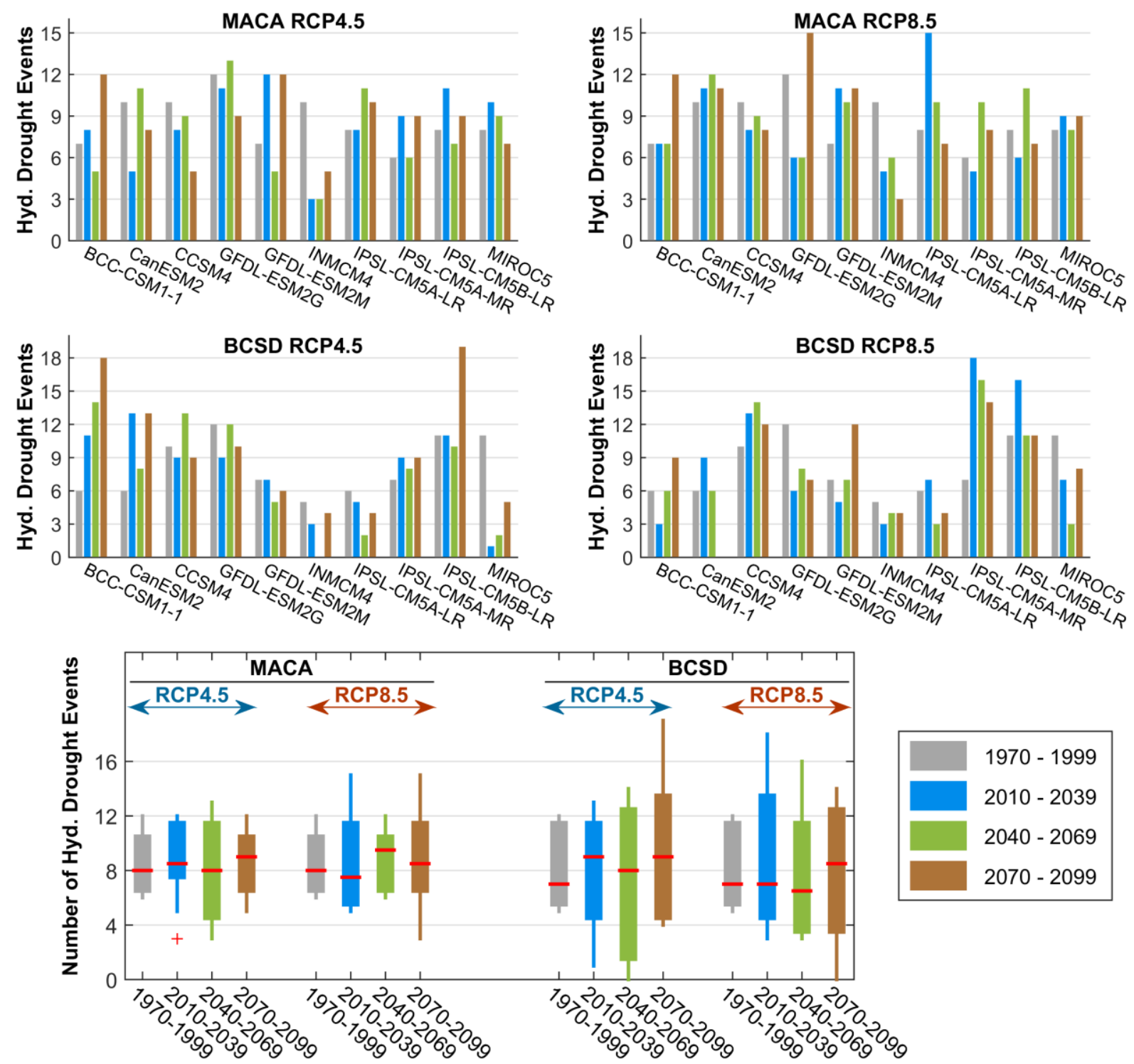

Figure 6. The number of hydrological drought events for each GCM in 30-year intervals. MACA results are shown in the top panel followed by BCSD in the middle. The boxplots at the bottom are showing the spread of 10 GCMs for each time span.

\subsubsection{Hydrological drought duration}

371 Figure 7 shows the total duration of hydrological droughts for each drought class, i.e. moderate, 372 severe, and extreme, for 30-year periods. Duration of hydrological drought is estimated for each 373 of the $10 \mathrm{GCMs}$, and the ensemble mean of $10 \mathrm{GCM}$ results is plotted for each case. Results

374 from MACA are plotted on top, followed by BCSD results plotted at the bottom. The observed 375 duration of moderate, severe, and extreme hydrological droughts are 21, 9, and 13 months, 
respectively, which is slightly overestimated by the GCMs. Results from all scenarios indicate

377 an increase in the duration of hydrological drought. Inter-decadal analysis of BCSD results

378 shows that there is not much change in the duration of moderate droughts. However, extreme

379 droughts are expected to increase significantly, especially in distant future (2070-2099).

380 Considering the total duration of the three drought classes, both datasets indicate about 50

381 months of drought in historical period (1970-1999), and about 80 months for the distant future

382 period (2070-2099); estimating 60\% increase in duration of drought for distant future. Overall,

383 BCSD shows longer duration of extreme drought than MACA.

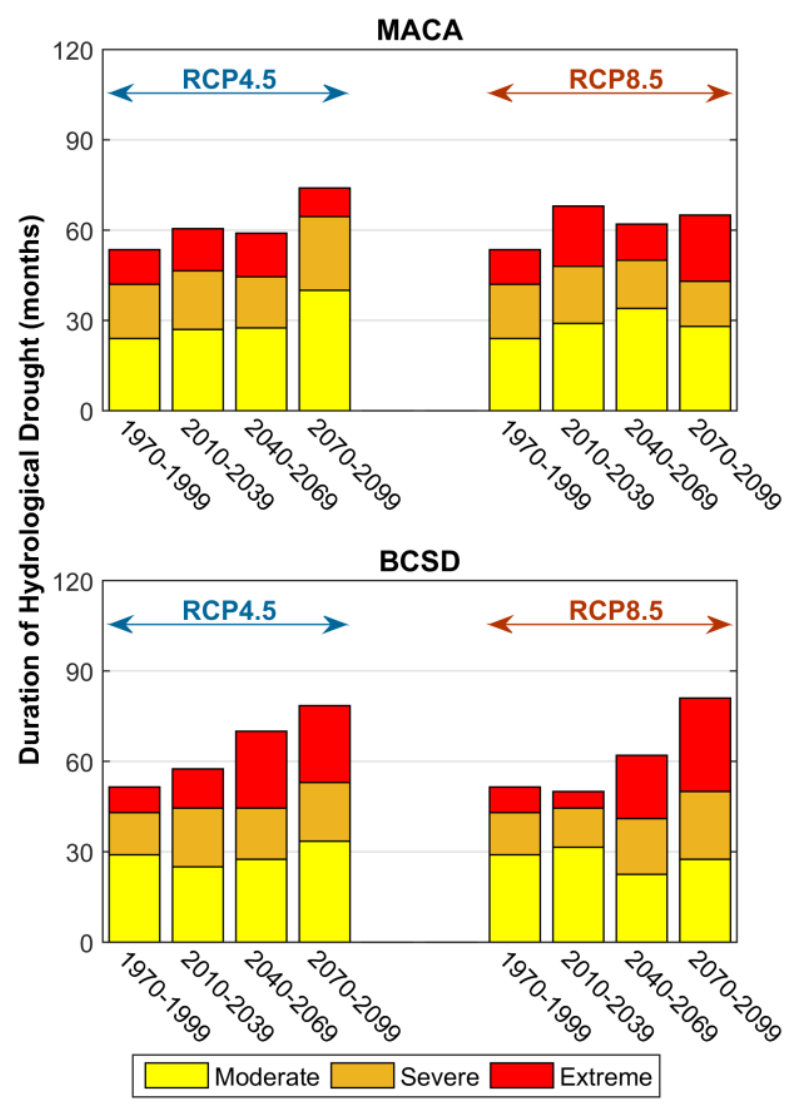

385 Figure 7. Duration of hydrological drought in 30-year time intervals. In each case, duration of drought is calculated for each GCM, and then the ensemble mean of $10 \mathrm{GCMs}$ is plotted in the figure.

\subsubsection{Hydrological drought intensity}

In order to understand how the intensity of future hydrological droughts is changing, the Mann-

Kendall trend test is utilized and the linear trend of hydrological drought index (SSI) is 
calculated. This is done for each scenario for the period of 2010-2099. Figure 8 shows the trend

391 of SSI calculated for each GCM. In the figure, MACA results are shown at the top, followed by BCSD. For each case, the $p$-value of trend test is computed at the significance level $(\alpha=0.05)$,

393 and the models showing p-values less than 0.05 are considered to have significantly 394 positive/negative trend, which are plotted with square marks. Overall, results from most models 395 in both datasets indicate an increase in the intensity of future hydrological drought. Large 396 uncertainty is found among different model projections.

397

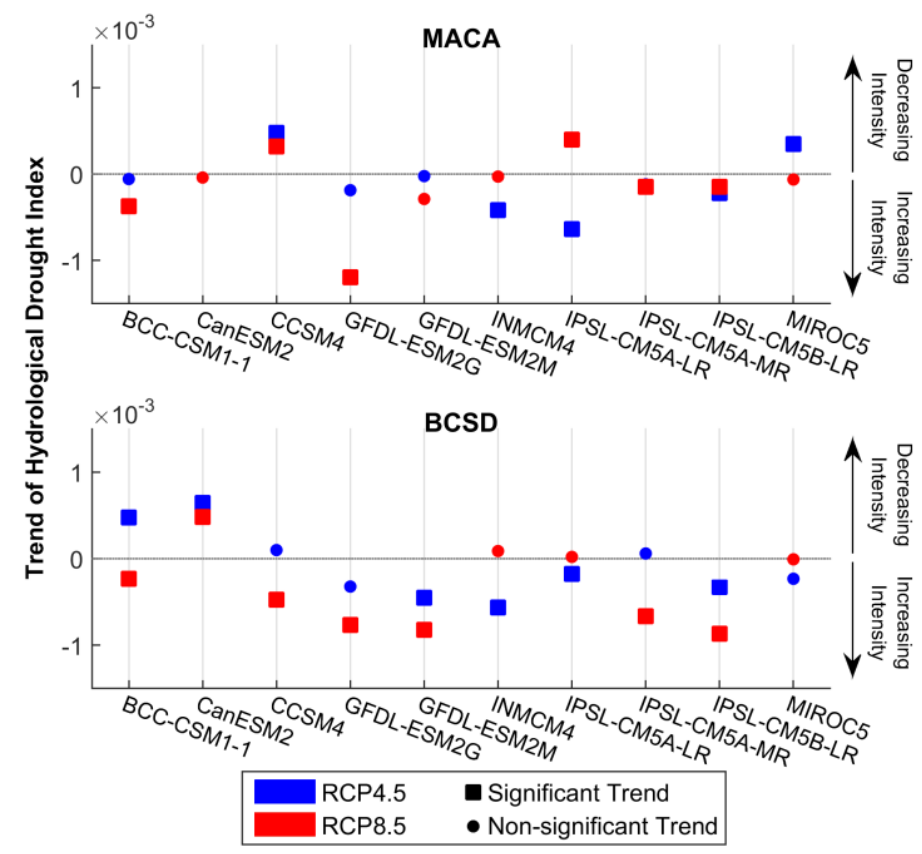

Figure 8. Long-term trend of hydrological drought index. For each GCM, trend is calculated for the period of 2010-2099 for MACA (top) and BCSD (bottom) datasets. Significance of the trend is examined using the Mann-Kendall test.

\section{DISCUSSION}

Drought, as an environmental disaster, can impose serious challenges to human beings and economy, and is among the costliest natural hazards. Population growth and agricultural expansion have increased the water demand, and climate change is believed to exacerbate water security conditions (Kong et al., 2016; Sun et al., 2015b). Drought is a complex phenomenon 
and it is affected by different variables, and increase in only temperature does not necessarily

407 translate to drought (Sheffield et al., 2012).

408 Model uncertainty is a primary source of uncertainty in future climate projections. Therefore, 409 selecting the models with higher accuracy is crucial for subsiding the uncertainties. Many 410 studies evaluated the accuracy of climate models, few of which assessed GCM fidelity in terms 411 of drought projection (Abatzoglou and Rupp, 2017). Such evaluations can reveal the low412 frequency internal climate variability of models.

413 In order to understand the accuracy of GCMs for drought projection, drought indices calculated 414 from each GCM is compared to the observed drought indices using Taylor diagrams (Taylor, 415 2000), and the results are shown in Figure S3. While SPI and SPEI indicate similar patterns, 416 MACA and BCSD exhibit differences. For instance, 8 out of 10 MACA models show negative 417 correlation with observed SPI, whereas half of the BCSD models indicate positive correlation. 418 In general, BCSD shows lower root mean square difference than MACA for meteorological 419 drought simulations. For the case of hydrological drought (SSI), both MACA and BCSD 420 indicate similar results, with the former having slightly lower RMS. Generally, there is low 421 similarity in the performance of the GCMs for meteorological and hydrological droughts.

422 Mizukami et al. (2016) assessed three downscaling techniques and demonstrated that the results can be different as high as $500 \mathrm{~mm} /$ year for annual precipitation and $0.4^{\circ} \mathrm{C}$ for mean annual temperature. Such differences are not uniform among different months and since the 425 downscaling techniques are usually applied separately for each month, the intra-seasonal 426 differences (which are utilized for drought assessment) would be even larger (Rana and 427 Moradkhani, 2015). Recently, Ahmadalipour et al. (2017a) performed an uncertainty 428 assessment of projected climate variables across the Columbia River Basin. They concluded 429 that downscaling uncertainty contributes a considerable share in the total uncertainty, especially 430 in summer, and it can be larger than the RCP uncertainty for precipitation. Therefore, it can be 
431 concluded that downscaling uncertainty can substantially affect the results of drought analysis,

432 especially at regional analyses.

433 The results of projected meteorological and hydrological droughts show different

434 characteristics. For instance, SPI indicates a decrease in the number of meteorological drought

435 events, while SSI shows a slight increase in the number of hydrological drought events (Figures

4362 and 6). BCSD shows increasing drought duration in most cases for both meteorological and

437 hydrological drought projections, whereas MACA indicates decreasing drought duration of

438 SPI, insignificant change for duration of SPEI, and an increase for duration of future

439 hydrological droughts (Figures 3 and 7). Furthermore, in terms of drought intensity, both

440 meteorological drought indices show decreasing intensity in RCP4.5 scenario. This is also the

441 case for SPI results of RCP8.5, and only SPEI in RCP8.5 projects an intensification in

442 meteorological drought (Figure 4).

443 The difference in projected characteristics of meteorological and hydrological drought can be

444 primarily related to the changes in precipitation and temperature patterns affecting snowpack,

445 snowmelt, and soil moisture. The long-term changes of precipitation, and maximum and

446 minimum temperature across Willamette Basin are plotted in Figure 9 and Figure S1 for both

447 datasets and both scenarios. Figure 9 shows the spatial changes for near future and distant

448 future. From the figure, increase in TMax and TMin reveal similar spatial patterns in both

449 datasets. RCP4.5 and RCP8.5 indicate similar temperature increase in near future with almost

$450 \quad 1.4^{\circ} \mathrm{C}$ increase. For distant future, RCP4.5 shows $2.2^{\circ} \mathrm{C}$ temperature increase, while RCP8.5

451 projects a temperature increase of about $5^{\circ} \mathrm{C}$. For precipitation, most cases indicate an increase

452 in precipitation at western coastal regions as well as the eastern mountainous areas. Slightly

453 decreasing precipitation is projected in near future for the central regions of the basin. 

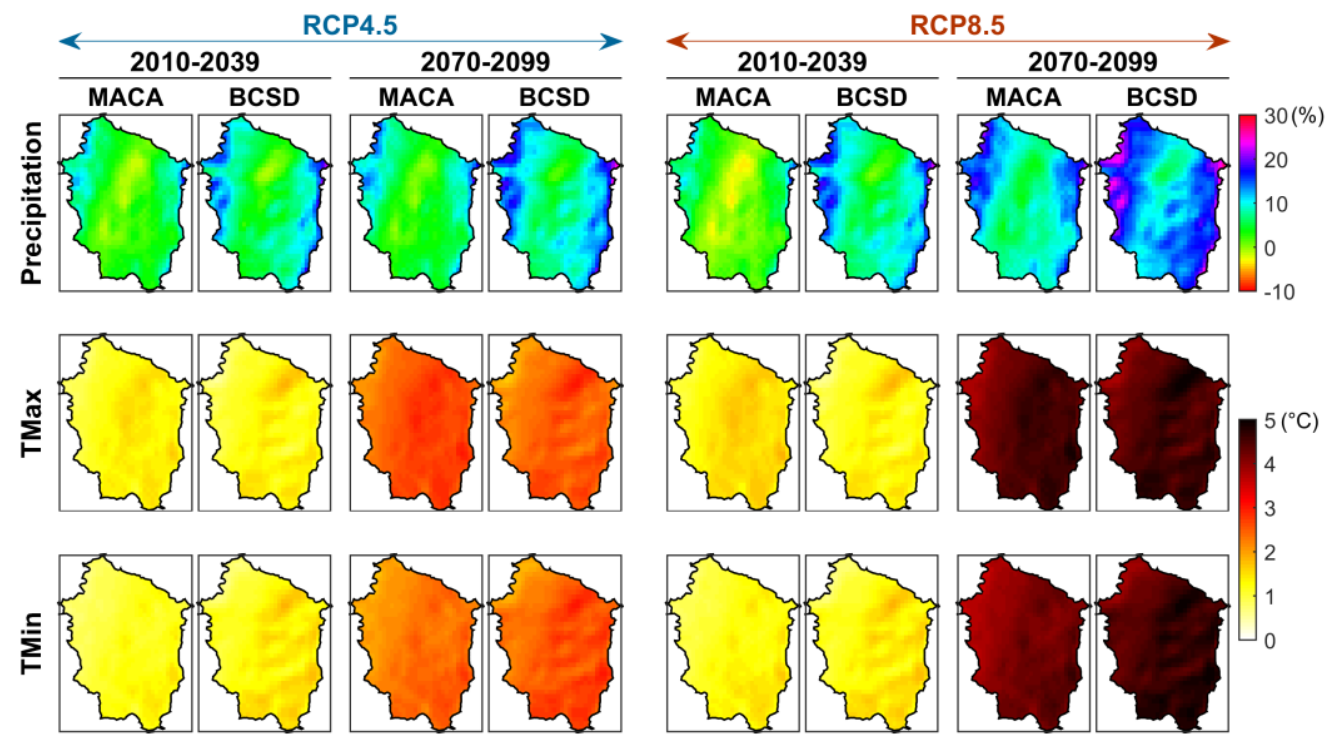

455 Figure 9. Future changes of climate variables in near future and distant future compared to the historical observation. In each plot, the ensemble mean of $10 \mathrm{GCM}$ projections is compared to the historical observation.

Besides the undeniable role of precipitation in meteorological drought, temperature changes show inevitable effects. From Figure 9, significant increase is found in minimum and maximum future temperature. An explicit effect of the rise in temperature is that it increases evapotranspiration, reduces soil moisture, and increases infiltration and percolation, all of which consequently decrease runoff and streamflow. However, a more crucial impact of temperature rise is its effect on snowpack and snowmelt (Hamlet et al., 2005). The rise of temperature may alter snowfall to rainfall, which would decrease the amount of snowpack stored and increase the streamflow in high-flow seasons (Knowles et al., 2006). Furthermore, increase in temperature may result in earlier spring onset and earlier snowmelt (Cayan et al., 2001). Since Willamette Basin receives precipitation mostly in high-flow months, discharge is mainly driven by snowmelt in low-flow season (Dralle et al., 2015). Therefore, a decrease in snowpack can substantially affect the summer discharge, which consequently results in more severe hydrological droughts.

471 The above-mentioned effects of temperature on snowpack can explain the patterns of monthly streamflow trends (shown in Figure 5) as well as the dissimilarities between meteorological and 
473 hydrological drought characteristics of future. Moreover, increase in evapotranspiration will

474 affect the irrigation water demand, and would alter characteristics of agricultural droughts.

475 Therefore, there is a need to objectively analyze the role of hydrological states and fluxes

476 (runoff, soil moisture, evapotranspiration, and snow water equivalent) in hydrological droughts,

477 and understand the controlling factor of drought.

478 The current study identified possible future changes of drought characteristics in a region with

479 abundant water resources, which is expected to receive more precipitation in future. The results 480 corroborated that drought can be intensified in future, notwithstanding the precipitation 481 increase.

\section{SUMMARY AND CONCLUSION}

483 This study investigated the changes in hydro-meteorological drought characteristics over the

484 Willamette basin using downscaled CMIP5 climate datasets. The results are based on a simulation approach using the outputs of an ensemble of 10 pre-selected climate models to run a hydrologic model. Different spatiotemporal characteristics of drought are analyzed using three drought indices, i.e. Standardized Precipitation Index, Standardized Precipitation Evapotranspiration Index, and Standardized Streamflow Index. Different sources of uncertainty arising from the GCMs, downscaling methods, and concentration pathways are also quantified for the period of 1970-1999 and 2010-2099. For hydrological simulations, PRMS model is

491 implemented using the projections of each GCM as forcing.

492 The conclusions from the results are summarized as follows:

- The calibration results revealed that streamflow simulations from the PRMS are in good agreement with observation for almost all calibration points.

- Based on the results of the two meteorological drought indices used for the current and future climate, significant changes are anticipated for the future drought characteristics of the Basin. Considering the SPEI results, the frequency and duration of meteorological 
drought events is expected to increase in most cases. Whereas SPI indicates decreasing intensity and frequency in most cases.

- According to the results, the duration and intensity of hydrological drought events are estimated to increase. Furthermore, the results show increasing trend in streamflow of high-flow months and decreasing trend in streamflow of low-flow months, indicating higher risk of winter floods and summer droughts.

- The temperature changes will alter the amount of snowpack as well as the snowmelt onset, which will change the streamflow patterns, resulting in exacerbated hydrological droughts.

- The comparative analysis of uncertainty from different sources considered in this study shows that the GCM uncertainty is the highest among other sources.

This study confirms that the concurrent analysis of meteorological and hydrological droughts

is necessary and requires more attention as they may demonstrate distinct trends and

511 characteristics. More importantly, studying meteorological drought using the SPI is inadequate

512 for analyzing the impacts of climate change, and the role of temperature should also be considered in drought assessments.

\section{ACKNOWLEDGEMENTS}

515 The authors are thankful for the financial support provided by NOAA-MAPP program, grant $516 \quad$ NA140AR4310234.

\section{REFERENCES}

Abatzoglou, J.T., Barbero, R., Wolf, J.W., Holden, Z.A., 2014. Tracking Interannual Streamflow Variability with Drought Indices in the U.S. Pacific Northwest. J. Hydrometeorol. 15, 1900-1912. doi:10.1175/JHM-D-13-0167.1

Abatzoglou, J.T., Brown, T.J., 2012. A comparison of statistical downscaling methods suited for wildfire applications. Int. J. Climatol. 32, 772-780. doi:10.1002/joc.2312 
Abatzoglou, J.T., Rupp, D.E., 2017. Evaluating climate model simulations of drought for the northwestern United States. Int. J. Climatol.

Ahmadalipour, A., Moradkhani, H., Rana, A., 2017a. Accounting for downscaling and model uncertainty in fine-resolution seasonal climate projections over the Columbia River Basin. Clim. Dyn. 1-17. doi:10.1007/s00382-017-3639-4

Ahmadalipour, A., Moradkhani, H., Svoboda, M., 2016. Centennial drought outlook over the CONUS using NASA-NEX downscaled climate ensemble. Int. J. Climatol. n/a-n/a. doi:10.1002/joc.4859

Ahmadalipour, A., Moradkhani, H., Yan, H., Zarekarizi, M., 2017b. Remote Sensing of Drought: Vegetation, Soil Moisture and Data Assimilation, in: Remote Sensing of Hydrological Extremes. Springer International Publishing Switzerland, pp. 121-149.

Ahmadalipour, A., Rana, A., Moradkhani, H., Sharma, A., 2015. Multi-criteria evaluation of CMIP5 GCMs for climate change impact analysis. Theor. Appl. Climatol. doi:10.1007/s00704-015-1695-4

Allen, R.G., Pereira, L.S., Raes, D., Smith, M., 1998. Crop evapotranspiration-Guidelines for computing crop water requirements-FAO Irrigation and drainage paper 56. FAO, Rome 300, D05109.

Anderson, M.C., Hain, C., Otkin, J., Zhan, X., Mo, K., Svoboda, M., Wardlow, B., Pimstein, A., 2013. An intercomparison of drought indicators based on thermal remote sensing and NLDAS-2 simulations with US Drought Monitor classifications. J. Hydrometeorol. 14, $1035-1056$.

Azmi, M., Rüdiger, C., Walker, J.P., 2016. A data fusion-based drought index. Water Resour. Res.

Berghuijs, W.R., Woods, R.A., Hrachowitz, M., 2014. A precipitation shift from snow towards rain leads to a decrease in streamflow. Nat. Clim. Chang. 4, 583-586.

Cayan, D.R., Dettinger, M.D., Kammerdiener, S.A., Caprio, J.M., Peterson, D.H., 2001. Changes in the onset of spring in the western United States. Bull. Am. Meteorol. Soc. 82, 399-415.

Chen, H., Sun, J., 2017. Anthropogenic warming has caused hot droughts more frequently in China. J. Hydrol. 544, 306-318.

Dai, A., 2012. Increasing drought under global warming in observations and models. Nat. Clim. Chang. 3, 52-58. doi:10.1038/nclimate1633

Dai, A., 2011. Drought under global warming: a review. Wiley Interdiscip. Rev. Clim. Chang. $2,45-65$.

Demirel, M.C., Booij, M.J., Hoekstra, A.Y., 2013. Identification of appropriate lags and temporal resolutions for low flow indicators in the River Rhine to forecast low flows with different lead times. Hydrol. Process. 27, 2742-2758. doi:10.1002/hyp.9402

Diffenbaugh, N.S., Scherer, M., Ashfaq, M., 2013. Response of snow-dependent hydrologic extremes to continued global warming. Nat. Clim. Chang. 3, 379-384.

Diffenbaugh, N.S., Swain, D.L., Touma, D., 2015. Anthropogenic warming has increased drought risk in California. Proc. Natl. Acad. Sci. 112, 201422385. doi:10.1073/pnas.1422385112

Donohue, R.J., McVicar, T.R., Roderick, M.L., 2010. Assessing the ability of potential evaporation formulations to capture the dynamics in evaporative demand within a 
changing climate. J. Hydrol. 386, 186-197.

Dralle, D.N., Karst, N.J., Thompson, S.E., 2015. Dry season streamflow persistence in seasonal climates. Water Resour. Res.

Duan, Q.Y., Gupta, V.K., Sorooshian, S., 1993. Shuffled complex evolution approach for effective and efficient global minimization. J. Optim. Theory Appl. 76, 501-521. doi:10.1007/BF00939380

Feng, X., Porporato, A., Rodriguez-Iturbe, I., 2013. Changes in rainfall seasonality in the tropics. Nat. Clim. Chang. 3, 811-815.

Gupta, H. V, Kling, H., Yilmaz, K.K., Martinez, G.F., 2009. Decomposition of the mean squared error and NSE performance criteria: Implications for improving hydrological modelling. J. Hydrol. 377, 80-91.

Halmstad, A., Najafi, M.R., Moradkhani, H., 2013. Analysis of precipitation extremes with the assessment of regional climate models over the Willamette River Basin, USA. Hydrol. Process. 27, 2579-2590. doi:10.1002/hyp.9376

Hamlet, A.F., Mote, P.W., Clark, M.P., Lettenmaier, D.P., 2005. Effects of temperature and precipitation variability on snowpack trends in the Western United States*. J. Clim. 18, $4545-4561$.

Hannaford, J., Lloyd-Hughes, B., Keef, C., Parry, S., Prudhomme, C., 2011. Examining the large-scale spatial coherence of European drought using regional indicators of precipitation and streamflow deficit. Hydrol. Process. 25, 1146-1162.

Hargreaves, G.H., Samani, Z.A., 1985. Reference crop evapotranspiration from temperature. Appl. Eng. Agric. 1, 96-99.

Hay, L.E., Leavesley, G.H., Clark, M.P., Markstrom, S.L., Viger, R.J., Umemoto, M., 2006. Step Wise, Multiple Objective Calibration of A Hydrologic Model For A Snowmelt Dominated Basin. J. Am. Water Resour. Assoc. 42, 877-890. doi:10.1111/j.17521688.2006.tb04501.x

Hay, L.E., Umemoto, M., 2007. Multiple-objective stepwise calibration using Luca. US Geological Survey.

Huang, S., Huang, Q., Chang, J., Leng, G., 2015. Linkages between hydrological drought, climate indices and human activities: a case study in the Columbia River basin. Int. J. Climatol. n/a-n/a. doi:10.1002/joc.4344

Jeong, D. Il, Sushama, L., Naveed Khaliq, M., 2014. The role of temperature in drought projections over North America. Clim. Change 127, 289-303. doi:10.1007/s10584-0141248-3

Jiang, M., Felzer, B.S., Sahagian, D., 2016. Predictability of Precipitation Over the Conterminous US Based on the CMIP5 Multi-Model Ensemble. Sci. Rep. 6.

Jung, I.-W., Chang, H., Moradkhani, H., 2011. Quantifying uncertainty in urban flooding analysis considering hydro-climatic projection and urban development effects. Hydrol. Earth Syst. Sci. 15, 617-633. doi:10.5194/hess-15-617-2011

Jung, I.W., Chang, H., 2012. Climate change impacts on spatial patterns in drought risk in the Willamette River Basin, Oregon, USA. Theor. Appl. Climatol. 108, 355-371.

Kendall, M.G., 1948. Rank correlation methods.

Kharin, V. V., Zwiers, F.W., Zhang, X., Wehner, M., 2013. Changes in temperature and precipitation extremes in the CMIP5 ensemble. Clim. Change 119, 345-357. 
Knowles, N., Dettinger, M.D., Cayan, D.R., 2006. Trends in snowfall versus rainfall in the western United States. J. Clim. 19, 4545-4559.

Kong, D., Miao, C., Wu, J., Duan, Q., 2016. Impact assessment of climate change and human activities on net runoff in the Yellow River Basin from 1951 to 2012. Ecol. Eng. 91, 566573.

Leavesley, G.H., Stannard, L.G., Singh, V.P., 1995. The precipitation-runoff modeling systemPRMS. Comput. Model. watershed Hydrol. 281-310.

Legesse, D., Vallet-Coulomb, C., Gasse, F., 2003. Hydrological response of a catchment to climate and land use changes in Tropical Africa: case study South Central Ethiopia. J. Hydrol. 275, 67-85. doi:10.1016/S0022-1694(03)00019-2

Livneh, B., Rosenberg, E.A., Lin, C., Nijssen, B., Mishra, V., Andreadis, K.M., Maurer, E.P., Lettenmaier, D.P., 2013. A Long-Term Hydrologically Based Dataset of Land Surface Fluxes and States for the Conterminous United States: Update and Extensions*. J. Clim. 26, 9384-9392. doi:10.1175/JCLI-D-12-00508.1

Lu, J., Sun, G., Mcnulty, S.G., Amatya, D.M., 2005. a Comparison of Six Potential Evapotranspiration Methods for Regional Use in the Southeastern United States 129414 , 621-633.

Mazrooei, A., Sinha, T., Sankarasubramanian, A., Kumar, S., Peters-Lidard, C.D., 2015. Decomposition of sources of errors in seasonal streamflow forecasting over the US Sunbelt. J. Geophys. Res. Atmos. 120.

McKee, T.B., Doeskin, N.J., Kleist, J., 1993. The relationship of drought frequency and duration to time scales, in: 8th Conf. on Applied Climatology. Anaheim, Canada OR Am. Meteorol. Soc., pp. 179-184.

Mizukami, N., Clark, M.P., Gutmann, E.D., Mendoza, P.A., Newman, A.J., Nijssen, B., Livneh, B., Hay, L.E., Arnold, J.R., Brekke, L.D., 2016. Implications of the methodological choices for hydrologic portrayals of climate change over the contiguous United States: statistically downscaled forcing data and hydrologic models. J. Hydrometeorol. 17, 7398.

Mote, P.W., Salathé, E.P., 2010. Future climate in the Pacific Northwest. Clim. Change 102, 29-50. doi:10.1007/s10584-010-9848-Z

Najafi, M.R., Moradkhani, H., Jung, I.W., 2011. Assessing the uncertainties of hydrologic model selection in climate change impact studies. Hydrol. Process. 25, 2814-2826. doi:10.1002/hyp.8043

Nalbantis, I., 2008. Evaluation of a Hydrological Drought Index 67-77.

Nalbantis, I., Tsakiris, G., 2009. Assessment of hydrological drought revisited. Water Resour. Manag. 23, 881-897.

Nash, J.E., Sutcliffe, J. V, 1970. River flow forecasting through conceptual models part I -- A discussion of principles. J. Hydrol. 10, 282-290.

Palmer, W.C., 1965. Meteorological drought. US Department of Commerce, Weather Bureau Washington, DC, USA.

655 Risley, J., Moradkhani, H., Hay, L., Markstrom, S., 2011. Statistical Comparisons of 
Watershed-Scale Response to Climate Change in Selected Basins across the United States. Earth Interact. 15, 1-26. doi:10.1175/2010EI364.1

Safeeq, M., Grant, G.E., Lewis, S.L., Kramer, M.G., Staab, B., 2014. A geohydrologic framework for characterizing summer streamflow sensitivity to climate warming in the Pacific Northwest, USA. Hydrol. Earth Syst. Sci. 11, 3693-3710. doi:10.5194/hessd-113315-2014

Schyns, J.F., Hoekstra, A.Y., Booij, M.J., 2015. Review and classification of indicators of green water availability and scarcity. Hydrol. Earth Syst. Sci. Discuss. 12, 5519-5564. doi:10.5194/hessd-12-5519-2015

Sheffield, J., Wood, E.F., Roderick, M.L., 2012. Little change in global drought over the past 60 years. Nature 491, 435-8. doi:10.1038/nature11575

Shukla, S., Safeeq, M., Aghakouchak, A., Guan, K., Funk, C., 2015. Temperature impacts on the water year 2014 drought in California 1-10. doi:10.1002/2015GL063666.Received

Shukla, S., Wood, A.W., 2008. Use of a standardized runoff index for characterizing hydrologic drought. Geophys. Res. Lett. 35.

Sima, S., Ahmadalipour, A., Tajrishy, M., 2013. Mapping surface temperature in a hyper-saline lake and investigating the effect of temperature distribution on the lake evaporation. Remote Sens. Environ. 136, 374-385.

Sohrabi, M.M., Ryu, J.H., Abatzoglou, J., Tracy, J., 2015. Development of Soil Moisture Drought Index to Characterize Droughts. J. Hydrol. Eng. 4015025. doi:10.1061/(ASCE)HE.1943-5584.0001213

Stagge, J.H., Tallaksen, L.M., Gudmundsson, L., Van Loon, A.F., Stahl, K., 2015. Candidate Distributions for Climatological Drought Indices (SPI and SPEI). Int. J. Climatol. 4040, n/a-n/a. doi:10.1002/joc.4267

Strzepek, K., Yohe, G., Neumann, J., Boehlert, B., 2010. Characterizing changes in drought risk for the United States from climate change. Environ. Res. Lett. 5, 44012. doi:10.1088/1748-9326/5/4/044012

Sun, Q., Miao, C., Duan, Q., 2015a. Extreme climate events and agricultural climate indices in China: CMIP5 model evaluation and projections. Int. J. Climatol. n/a-n/a. doi: $10.1002 /$ joc. 4328

Sun, Q., Miao, C., Duan, Q., 2015b. Comparative analysis of CMIP3 and CMIP5 global climate models for simulating the daily mean, maximum, and minimum temperatures and daily precipitation over China. J. Geophys. Res. Atmos. 120, 4806-4824.

Swain, S., Hayhoe, K., 2015. CMIP5 projected changes in spring and summer drought and wet conditions over North America. Clim. Dyn. 44, 2737-2750. doi:10.1007/s00382-0142255-9

Taylor, K.E., 2000. Summarizing multiple aspects of model performance in a single diagram. Program for Climate Model Diagnosis and Intercomparison, Lawrence Livermore National Laboratory, University of California.

Taylor, K.E., Stouffer, R.J., Meehl, G. a., 2012. An Overview of CMIP5 and the Experiment Design. Bull. Am. Meteorol. Soc. 93, 485-498. doi:10.1175/BAMS-D-11-00094.1

Touma, D., Ashfaq, M., Nayak, M. a., Kao, S.-C., Diffenbaugh, N.S., 2015. A multi-model and multi-index evaluation of drought characteristics in the 21 st century. J. Hydrol. 526, 196207. doi:10.1016/j.jhydrol.2014.12.011 
Turner, D.P., Conklin, D.R., Bolte, J.P., 2015. Projected climate change impacts on forest land cover and land use over the Willamette River Basin, Oregon, USA. Clim. Change 133, $335-348$.

Van Loon, A.F., 2015. Hydrological drought explained. Wiley Interdiscip. Rev. Water n/a-n/a. doi:10.1002/wat2.1085

Van Loon, A.F., Van Lanen, H.A.J., 2013. Making the distinction between water scarcity and drought using an observation-modeling framework. Water Resour. Res. 49, 1483-1502. doi:10.1002/wrcr.20147

Vicente-Serrano, S., Cabello, D., Tomás-Burguera, M., Martín-Hernández, N., Beguería, S., Azorin-Molina, C., Kenawy, A., 2015. Drought Variability and Land Degradation in Semiarid Regions: Assessment Using Remote Sensing Data and Drought Indices (19822011). Remote Sens. 7, 4391-4423. doi:10.3390/rs70404391

Vicente-Serrano, S.M., Beguería, S., López-Moreno, J.I., 2010. A multiscalar drought index sensitive to global warming: The standardized precipitation evapotranspiration index. J. Clim. 23, 1696-1718. doi:10.1175/2009JCLI2909.1

Williams, a. P., Seager, R., Abatzoglou, J.T., Cook, B.I., Smerdon, J.E., Cook, E.R., 2015. Contribution of anthropogenic warming to California drought during 2012-2014. Geophys. Res. Lett. in press, 1-10. doi:10.1002/2015GL064924 
Table 1. The 10 GCMs used in this study and their characteristics.

\begin{tabular}{lllcc}
\hline Index & Model name & Institute & $\begin{array}{c}\text { Original } \\
\text { Resolution } \\
\text { (Lon } \times \text { Lat) }\end{array}$ & $\begin{array}{c}\text { Vertical } \\
\text { levels in } \\
\text { Atmosphere }\end{array}$ \\
\hline 1 & BCC-CSM1-1 & Beijing Climate Center, China Meteorological Administration & $2.8 \times 2.8$ & 26 \\
\hline 2 & CanESM2 & Canadian Centre for Climate Modeling and Analysis & $2.8 \times 2.8$ & $1.25 \times 0.94$ \\
\hline 3 & CCSM4 & National Center of Atmospheric Research, USA & $2.5 \times 2.0$ & 26 \\
\hline 4 & GFDL-ESM2G & NOAA Geophysical Fluid Dynamics Laboratory, USA & $2.5 \times 2.0$ \\
\hline 5 & GFDL-ESM2M & NOAA Geophysical Fluid Dynamics Laboratory, USA & $2.0 \times 1.5$ \\
\hline 6 & INMCM4 & Institute for Numerical Mathematics, Russia & $3.75 \times 1.8$ \\
\hline 7 & IPSL-CM5A-LR & Institut Pierre Simon Laplace, France & 21 \\
\hline 8 & IPSL-CM5A-MR & Institut Pierre Simon Laplace, France & 39 \\
\hline 9 & IPSL-CM5B-LR & Institut Pierre Simon Laplace, France & $2.5 \times 1.25$ \\
\hline 10 & MIROC5 & $\begin{array}{l}\text { Atmosphere and Ocean Research Institute (The University of Tokyo), } \\
\text { National Institute for Environmental Studies, and Japan Agency for } \\
\text { Marine-Earth Science and Technology }\end{array}$ & $1.4 \times 1.4$ \\
\hline
\end{tabular}


Table 2. The parameters calibrated in each step of the calibration process.

\begin{tabular}{|c|c|c|c|}
\hline Parameter & Min & Max & Parameter Description \\
\hline adjmix_rain_hru_mo & 0.6 & 1.4 & Factor to adjust rain proportion in mixed rain/ snow event \\
\hline cecn_coef & 2 & 10 & Convection condensation energy coefficient \\
\hline dday_intcp_hru & -60 & 10 & Intercept in relationship \\
\hline dday_slope_mth & 0.2 & 0.9 & Coefficient in relationship \\
\hline dprst_depth_avg & 48 & 250 & Average depth of depressions at maximum storage capacity. \\
\hline dprst_flow_coef & 0 & 0.3 & Coefficient in linear flow routing equation for open surface depressions. \\
\hline dprst_seep_rate_open & 0 & 0 & Coefficient used in linear seepage flow equation for open surface depressions. \\
\hline emis_noppt & 0.8 & 1 & Emissivity of air on days without precipitation \\
\hline fastcoef_lin & 0 & 0.8 & Coefficient to route preferential-flow storage down slope \\
\hline freeh2o_cap & 0 & 0.2 & Free-water holding capacity of snowpack \\
\hline gwflow_coef & 0 & 0.5 & Linear coefficient to compute groundwater discharge from each GWR \\
\hline gwsink_coef & 0 & 0.1 & percent \\
\hline gwstor_min & 0 & 1 & Depth (inches) \\
\hline jh_coef_hru_mth & 0 & 0.1 & Monthly air temperature coefficient used in Jensen-Haise potential ET computations \\
\hline K_coef & 1 & 24 & Travel time of flood wave from one segment to the next downstream segment \\
\hline op_flow_thres & 0.8 & 1 & Fraction of open depression storage above which surface runoff occurs for each time step \\
\hline potet_sublim & 0.1 & 0.8 & Proportion of PET that is sublimated from snow surface \\
\hline pref_flow_den & 0 & 0.1 & Fraction of the soil zone in which preferential flow occurs \\
\hline rain_cbh_adj_mo & 0.6 & 1.4 & Precipitation adjust factor for rain days \\
\hline sat_threshold & 1 & 15 & Water holding capacity of the gravity and preferential flow reservoirs. \\
\hline slowcoef_lin & 0 & 0.5 & Linear coefficient in equation to route gravity-reservoir storage down slope for each HRU \\
\hline slowcoef_sq & 0.1 & 0.3 & Non-linear coefficient in equation to route gravity- reservoir storage down slope for each HRU. \\
\hline smidx_coef & 0 & 0.1 & Coefficient in non-linear surface runoff contributing area algorithm \\
\hline snow_cbh_adj_mo & 0.6 & 1.4 & Precipitation adjust factor for snow days \\
\hline soil_moist_max & 2 & 10 & Maximum available water holding capacity of soil profile \\
\hline soil_rechr_max & 1.5 & 5 & Maximum available water holding capacity for soil recharge zone \\
\hline soil2gw_max & 0 & 0.5 & Maximum amount of capillary reservoir excess routed directly to the GWR \\
\hline
\end{tabular}




\begin{tabular}{lccl} 
sro_to_dprst & 0 & 1 & Fraction of pervious and impervious surface runoff that flows into surface depressions \\
\hline ssr2gw_rate & 0.1 & 0.8 & Linear coefficient used to route water from the gravity reservoir to the GWR \\
\hline tmax_allrain_hru_mo & 34 & 45 & If HRU tmax exceeds this value, precipitation assumed rain \\
\hline tmax_allsnow_hru & 30 & 40 & If HRU tmax is below this value, precipitation assumed snow \\
\hline va_open_exp & 0 & 1 & $\begin{array}{l}\text { Coefficient relating maximum surface area to the fraction that open depressions are full to computed } \\
\text { surface area }\end{array}$ \\
\hline
\end{tabular}

Table 3. Calibration and validation results at 20 NRNI points. The values in parentheses show the model performance over validation period. Note that the outlet of WRB is at TWSullivan, SVN5N.

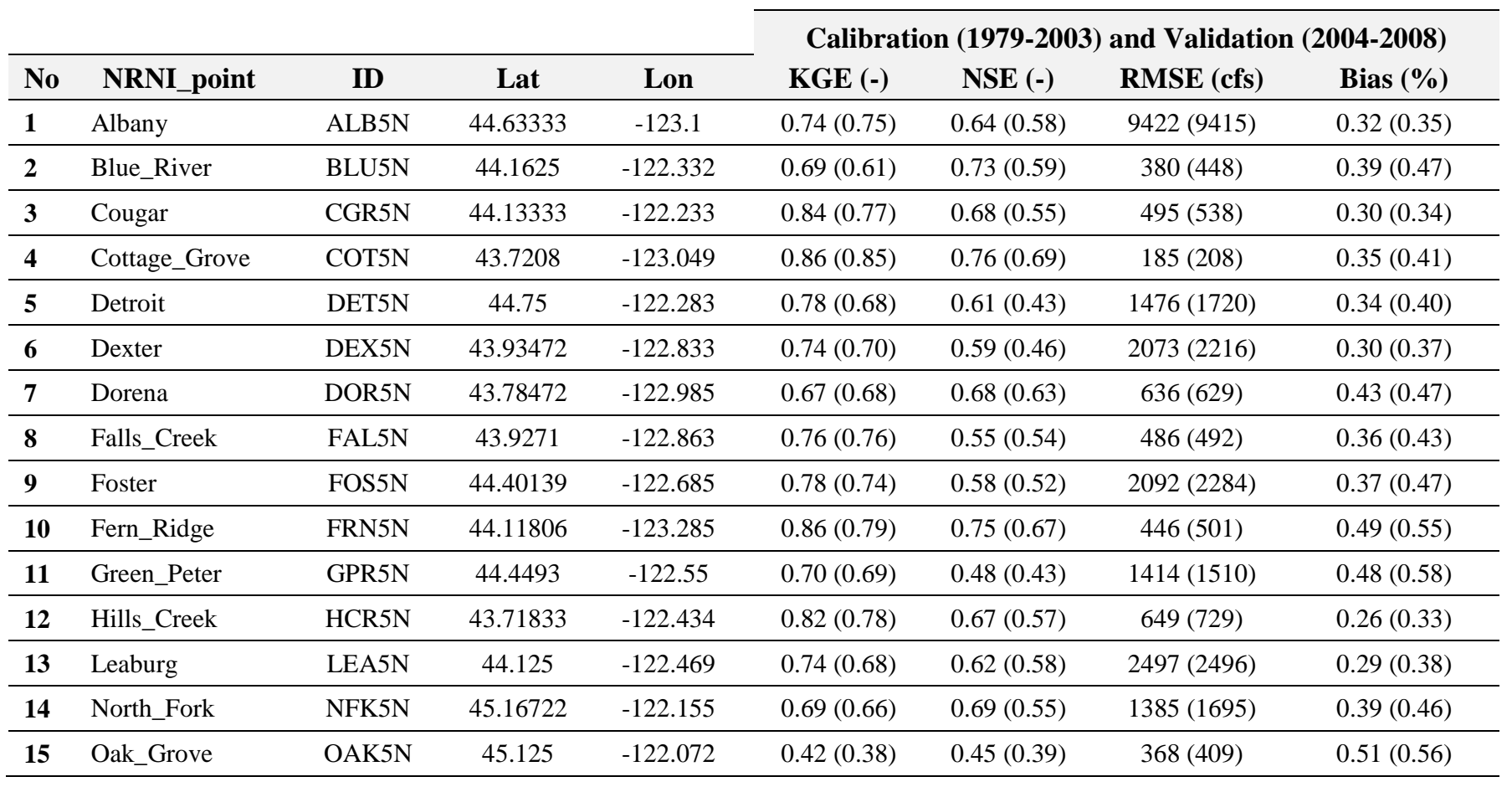




\begin{tabular}{llcccccccc}
$\mathbf{1 6}$ & River_Mill & RML5N & 45.3 & -122.353 & $0.81(0.69)$ & $0.67(0.49)$ & $1597(2023)$ & $0.32(0.42)$ \\
\hline $\mathbf{1 7}$ & Salem & SLM5N & 44.93333 & -123.033 & $0.71(0.75)$ & $0.53(0.54)$ & $15264(15296)$ & $0.36(0.40)$ \\
\hline $\mathbf{1 8}$ & Smith_Reservoir & SMH5N & 44.30556 & -122.044 & $0.74(0.52)$ & $0.56(0.01)$ & $81(109)$ & $0.53(0.75)$ \\
\hline $\mathbf{1 9}$ & TWSullivan & SVN5N & 45.34861 & -122.619 & $0.65(0.73)$ & $0.41(0.54)$ & $22181(20213)$ & $0.40(0.40)$ \\
\hline $\mathbf{2 0}$ & Walterville & WAV5N & 44.07 & -122.77 & $0.69(0.64)$ & $0.51(0.48)$ & $2856(2803)$ & $0.33(0.40)$ \\
\hline
\end{tabular}

